Article

\title{
The Influence of Transition Metals Addition on the Corrosion Resistance of Nanocrystalline Al Alloys Produced by Mechanical Alloying
}

\author{
Asiful Hossain Seikh ${ }^{1, *}$, Muneer Baig ${ }^{1}$, Hany Rizk Ammar ${ }^{2}$ and Mohammed Asif Alam ${ }^{1}$ \\ 1 AMI-Center of Excellence for Research in Engineering Material, King Saud University, Riyadh 11421, \\ Saudi Arabia; bmuneer@ksu.edu.sa (M.B.); moalam@ksu.edu.sa (M.A.A.) \\ 2 Metallurgical and Materials Engineering Department, Faculty of Petroleum and Mining Engineering, \\ Suez University, Suez 41522, Egypt; hany_ammar@uqac.ca \\ * Correspondence: aseikh@ksu.edu.sa; Tel.: +966-55-920-4166; Fax: +966-14676652
}

Academic Editor: Hugo F. Lopez

Received: 14 March 2016; Accepted: 8 June 2016; Published: 16 June 2016

\begin{abstract}
The corrosion resistance of nanocrystalline Al, Al-10 wt. \% Fe and Al-10 wt. \% Fe-5 wt. \% $\mathrm{Cr}$ alloys was investigated in $3.5 \% \mathrm{NaCl}$ solution using cyclic potentiodynamic polarization (CPP) and electrochemical impedance spectroscopy (EIS) techniques. The alloys were fabricated using mechanical alloying (MA) and heat induction sintering. When compared with the corrosion resistance of pure $\mathrm{Al}$, the experimental results indicated that the addition of $10 \mathrm{wt}$. \% Fe and $10 \mathrm{wt}$. \% Fe-5 wt. \% Cr to pure $\mathrm{Al}$ has resulted in an enhancement in the corrosion resistance of these newly fabricated alloys. The resistance to corrosion is due to enhanced microstructural stability along with the formation of stable oxide layer.
\end{abstract}

Keywords: nanocrystalline aluminum alloy; mechanical alloying; corrosion; polarization; EIS

\section{Introduction}

In the last few decades, aluminum ( $\mathrm{Al})$ and its alloys have gained importance in the automobile, aircraft and defense industries due to their attractive properties, such as high strength to weight ratio and good resistance against corrosion [1,2]. However, the increasing demand for the production of high strength and low weight alloys for high temperature applications has led to the modification of traditional manufacturing processes. Additionally, addition of transition metals (TM) in pure Al matrix could improve the strength of $\mathrm{Al}$ alloys at elevated temperatures. The added transition elements, such as $\mathrm{Fe}, \mathrm{Cr}$ and $\mathrm{Ti}$, form secondary phases with $\mathrm{Al}$. These newly formed phases provide the required microstructural stability to the alloy, thereby improving its strength even at elevated temperatures [3]. However, the solubility limit of these transition elements in Al matrix is very limited even with the modified processing methods.

To increase the solubility of transition elements other method, such as mechanical alloying (MA) based on solid-state processing, have recently gained importance. In addition to increasing the solubility limit, the MA process leads to the homogeneous dispersion of intermetallic into the base matrix thereby enhancing the microstructural stability of the processed alloy [4-7]. MA is a viable technique that can be effectively used to produce a high quality alloy. The various factors that directly influence the quality of the processed powders include processing medium, ball to powder weight ratio, and speed of alloying [6].

The coarse grained $\mathrm{Al}$ and its alloys exhibit excellent corrosion resistant properties due to the formation of an oxide layer [1,2,8-13]. However, when exposed to harsh atmospheric conditions or in a medium such as chloride solution, $\mathrm{Al}$ experiences uniform and pitting corrosion [12-14]. 
Due to the nano-size effect, the corrosion resistance exhibited by nanocrystalline materials differs from the corrosion resistance in coarse grained material. In passive environments, the nanocrystalline $\mathrm{Al}$ alloys exhibited an increase in their corrosion resistance [15]. An earlier investigation on the corrosion behavior of nanocrystalline $\mathrm{Al}-20 \mathrm{wt} . \% \mathrm{Cr}$ has reported an enhancement in the corrosion resistance of the synthesized alloy when compared to the corrosion resistance of nanocrystalline $\mathrm{Al}$. The observed enhancement in the resistance values was attributed to the nanocrystalline structure, successful addition of alloying element (Chromium) and the formation of Al-Cr intermetallics [16]. Another investigation on the corrosion resistance of the fabricated nanocrystalline $\mathrm{Al}-x \mathrm{Cr}$ alloy reported an increase in the corrosion resistance of the alloy when compared to the corrosion resistance of pure $\mathrm{Al}$ [17]. Similarly, an investigation on the influence of cooling rate on the microstructure and corrosion behavior of Al-Fe alloy has reported an increase in the corrosion resistance of the alloy with cooling rate. The increase in cooling rate was observed to increase the corrosion resistance of the alloy [18]. Sherif et al. [19] has observed an increase in the corrosion resistance of nanocrystalline Al with the addition of $\mathrm{Cu}$ and Ti. On a contrary, Ghosh et al. [20] observed the formation of pits on the surface of the nanocrystalline Ni-Cu alloy. The observed pits were found to be shallow and largely coupled, leading to formation of more uniform corrosion than the coarsed grained material. Liu et al. [21] concluded that the rate of corrosion is increased by nanocrystallization, if the products of corrosion are soluble. However, the corrosion products form a passive layer on material surface which decreases the rate of corrosion, if the corrosion products are insoluble.

In general, the corrosion behavior in nanocrystalline materials depends on various factors such as concentration of alloying element [8], manufacturing processes [22,23], microstructure [24,25] and environmental condition [26,27]. Due to the lower solubility limit of transition elements in Al matrix, very less attention has been given towards the fabrication of the bulk alloy and its characterization for corrosion resistant properties.

The present study is aimed to investigate the corrosion behavior of the fabricated nanocrystalline bulk Al, Al-10 wt. \% Fe and Al-10 wt. \% Fe-5 wt. \% Cr alloys in 3.5\% $\mathrm{NaCl}$ solution using EIS and CPP techniques.

\section{Experimental Procedure}

\subsection{Production of Ultrafine/Nanocrystalline Al, Al-10 wt. \% Fe and Al-10 wt. \% Fe-5 wt. \% Cr Alloys}

The initial powders used include; $\mathrm{Al}$ (99.95\%), Fe (99.95\%) and $\mathrm{Cr}$ (99.95\%) with an average particle size of 1, 5 and $4 \mu \mathrm{m}$, respectively. Before alloying, pure $\mathrm{Al}$ and proportionate mixtures of $\mathrm{Al}-10$ wt. \% Fe and Al-10 wt. \% Fe-5 wt. \% Cr were degassed at $423 \mathrm{~K}$ for $24 \mathrm{~h}$ in vacuum. The mixtures of degassed powders were charged into stainless steel containers of pulverisette-P5 planetary high energy ball mill. The mechanical milling (Al) and mechanical alloying (Al-10 wt. \% Fe and Al-10 wt. \% Fe-5 wt. \% Cr) was performed for $150 \mathrm{~h}$ under inert (Ar) atmosphere. Stearic acid ( $1 \mathrm{wt}$ \%) was used as a process control agent (PCA), to prevent the agglomeration of particles during milling. The milled powders were later charged into the graphite dies in a glove box. The graphite die was later introduced into the High Frequency Induction Heat Sintering (HFIHS) machine (ELTek, Seol, Korea) to produce sintered compacts. The sintering was performed in vacuum while the heating rate and sintering temperature was set to $823 \mathrm{~K} / \mathrm{min}$ and $823 \mathrm{~K}$, respectively. The hold time for sintering was set to $6 \mathrm{~min}$ with an applied pressure of $50 \mathrm{MPa}$. Further details on sample production can be found elsewhere [28].

\subsection{X-ray Diffraction (XRD)}

The X-ray diffraction of the alloy before and after corrosion was performed using an X-ray diffractometer (Bruker, Karlsruhe, Germany) with a standard $\mathrm{Cu}-\mathrm{K}_{\alpha}(\lambda=0.154 \mathrm{~nm})$ radiation. The $2 \theta$ range was selected from $30^{\circ}$ to $70^{\circ}$ to capture the most intense peaks of Al. The crystallite size of the sintered alloy was obtained using the Scherrer equation [29]. The crystallite size was calculated using 
the most intense peak of $\mathrm{Al}$ (111). The average crystallite size for pure $\mathrm{Al}, \mathrm{Al}-10 \mathrm{wt}$ \% Fe and Al-10 wt. $\%$ Fe-5 wt. \% Cr alloys was found to be $35 \mathrm{~nm}, 29 \mathrm{~nm}$ and $33 \mathrm{~nm}$, respectively.

\subsection{Microstructural Characterization of Sintered Alloy}

The microstructure of the sintered alloys was characterized using a field-emission scanning electron microscope (FESEM) with energy dispersive spectrometry (EDS) analyzer, manufactured by JOEL. The samples for SEM/EDS investigations were finely polished using sand papers of various sizes ranging from 180 to 4000 grit. The final polishing was performed using an emery cloth and alumina solution (1 micron) manufactured by Buehler (Braunschweig, Germany).

\subsection{Chemicals, Materials, and Electrochemical Cell}

The electrochemical experiments on the produced alloys were performed in a $3.5 \% \mathrm{NaCl}$ solution prepared from analytical grade reagents and distilled water. The processed nanocrystalline bulk $\mathrm{Al}$, Al-10 wt. \% Fe and Al-10 wt. \% Fe-5 wt. \% Cr alloys with $10 \mathrm{~mm}$ diameter, were used as the working electrode (WE). The $\mathrm{Ag} / \mathrm{AgCl}$ and platinum foil was used as a reference electrode (RE) and counter electrode (CE), respectively. The working electrode for electrochemical measurements was prepared by soldering a copper wire to one of its face and then cold mounted in resin and left to dry in air for $24 \mathrm{~h}$ at room temperature. Before measurements, the other face of the working electrode, which was not soldered, was first ground successively with metallographic emery paper of increasing fineness up to 1000 grit and further polished with 5, 1, 0.5, and $0.3 \mathrm{~mm}$ alumina slurries. The electrodes were then cleaned using doubly-distilled water, degreased with acetone, washed using doubly-distilled water again and finally dried with dry air [28].

\subsection{Electrochemical Experiments}

The cyclic potentiodynamic polarization (CPP) and Electrochemical Impedance Spectroscopy (EIS) experiments were performed on an Autolab system (Metrohm Autolab B.V., Utrecht, The Netherlands) by Metrohm (PGSTAT20). The EIS tests were performed after immersing the nanocrystalline sintered alloy in the test solution for $1 \mathrm{~h}$ at open circuit potential $\left(E_{\mathrm{OC}}\right)$ to confirm its stability with time. The EIS were measured with electrochemical cell at $E_{\mathrm{OC}}$ with applied $5 \mathrm{mV}$ sinusoidal perturbations in the frequency range of $100 \mathrm{kHz}-10 \mathrm{mHz}$ with 10 steps per decade. The CPP was conducted from the $E_{\mathrm{OC}}$ at the same positions and immediately after the EIS measurements. These tests were conducted by stepping the potential at a scan rate of $1.67 \mathrm{mV} \mathrm{s}^{-1}$ in the range of -1200 to $0.00 \mathrm{mV}$ against SCE at OCP. The potential was then scanned in the reverse direction at the same scan rate in order to complete the cycle test. All electrochemical experiments were carried out on a fresh surface of the electrode and a new test solution (in a cell contains $200 \mathrm{~mL}$ of the freely aerated stagnant $3.5 \% \mathrm{NaCl}$ ) at room temperature after $1 \mathrm{~h}$ immersion.

\section{Results and Discussion}

The SEM micrograph of nanocrystalline pure Al, Al-10 wt. \% Fe and Al-10 wt. \% Fe-5 wt. \% Cr as-sintered alloys along with the corresponding EDX are shown in Figure 1a-c. The SEM micrographs did not reveal any porosity in the sintered alloys. This implies that the alloys produced in this work were highly dense which is considered as one of the main advantages of using HFIHS technique. The EDX on the right side indicated the presence of expected elements in the micrograph. Again, no irregularity was observed in the EDX of all the alloys used in this investigation. 


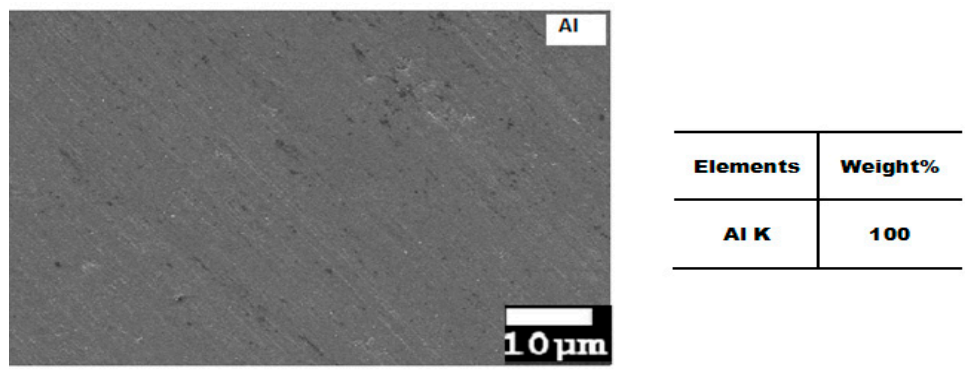

(a)

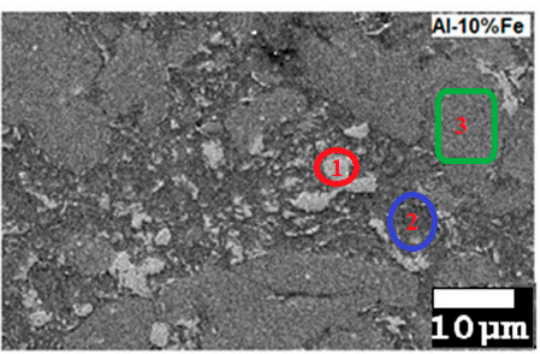

\begin{tabular}{c|c|c|c}
\hline Elements & \multicolumn{3}{|c}{ Weight\% } \\
\hline & 1 & 2 & 3 \\
\hline AI K & 92.25 & 87.34 & 86.64 \\
Fe K & 7.11 & 9.69 & 9.68 \\
Total & 100 & 100 & 100 \\
\hline
\end{tabular}

(b)

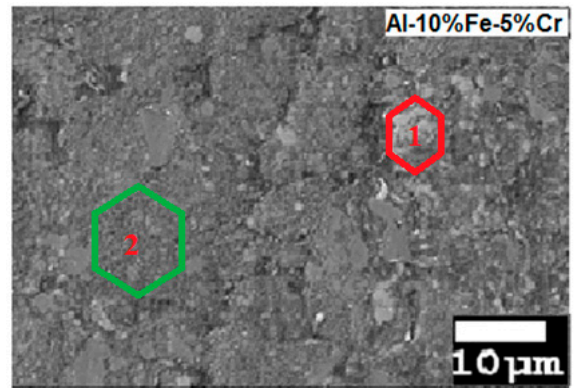

\begin{tabular}{c|c|c}
\hline Elements & \multicolumn{2}{|c}{ Weight\% } \\
\hline & 1 & 2 \\
\hline Al K & 87.96 & 84.23 \\
Cr K & 2.61 & 5.69 \\
Fe K & 9.43 & 10.09 \\
Total & 100 & 100 \\
\hline
\end{tabular}

(c)

Figure 1. SEM micrograph and EDX profile analysis obtained on the nanocrystalline $\mathrm{Al}(\mathbf{a}), \mathrm{Al}-10 \%$ $\mathrm{Fe}(\mathbf{b})$ and $\mathrm{Al}-10 \% \mathrm{Fe}-5 \% \mathrm{Cr}$ (c) alloy after sintering.

Figure $2 \mathrm{a}-\mathrm{c}$ shows the XRD peak profiles for the sintered pure $\mathrm{Al}, \mathrm{Al}-10 \mathrm{wt}$ \% Fe and Al-10 wt. \% Fe-5 wt. \% $\mathrm{Cr}$ alloy. In all the cases, the existence of $\alpha$-Al could be confirmed with reflections corresponding to (111), (200) and (220) planes of Al. The presence of Fe in Figure $2 \mathrm{~b}$ and the presence of $\mathrm{Cr}$ in Figure $2 \mathrm{c}$ are not obvious and this could be due to the partial overlapping of their peaks with Al peaks. However, the elemental composition of the sintered samples (shown in Figure 1) indicated the presence of Fe and $\mathrm{Cr}$ in the microstructure of the sintered alloy. The presence of the alloying elements appeared to be in the form of secondary phases. The XRD peaks shown in Figure 2, appeared to be broad indicating the occurrence of grain refinement due to milling. In case of Figure $2 b$, the formation of a new phase corresponding to $\mathrm{Al}_{6} \mathrm{Fe}$ was observed. Similarly, the formation of $\mathrm{Al}_{6} \mathrm{Fe}$, $\mathrm{Al}_{13} \mathrm{Fe}_{4}$ and $\mathrm{Al}_{13} \mathrm{Cr}_{2}$ secondary phases was observed in Figure 2c. These phases were formed during the sintering process which was performed at a high temperature (823 K). It is evident from SEM and XRD results that the presence of these phases or intermetallics in the sintered $\mathrm{Al}-10 \mathrm{wt}$. \% Fe and Al-10 wt. \% Fe-5 wt. \% Cr alloys enhanced the microstructural stability thereby imparting improved mechanical properties. 

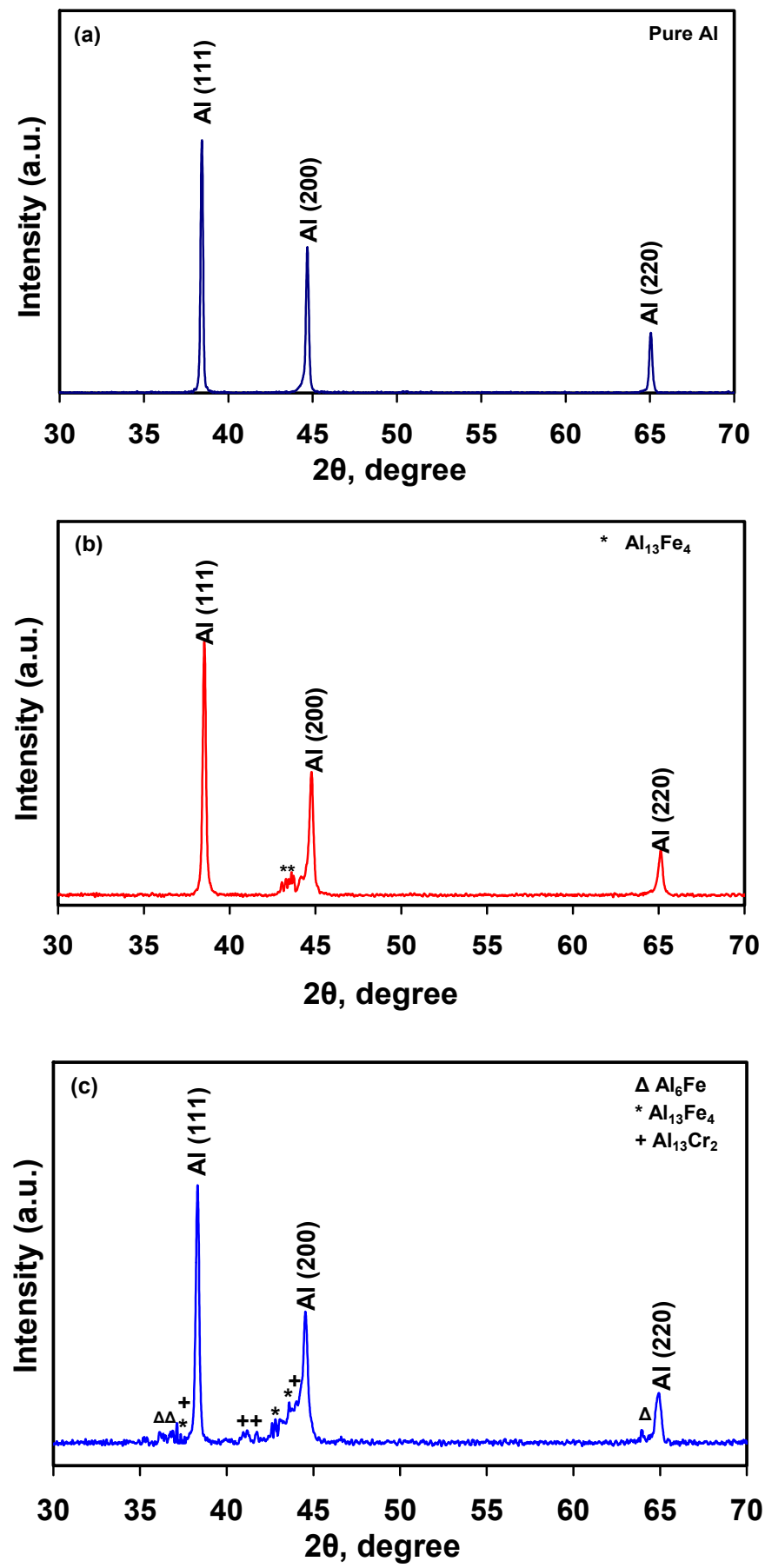

Figure 2. XRD analysis obtained for the nanocrystalline (a) $\mathrm{Al}$, (b) $\mathrm{Al}-10 \% \mathrm{Fe}$ and (c) $\mathrm{Al}-10 \% \mathrm{Fe}-5 \% \mathrm{Cr}$ alloy after sintering.

The $2 \theta$ values for the secondary phases $\mathrm{Al}_{13} \mathrm{Fe}_{4}$ shown in Figure $2 \mathrm{~b}$ were found to be $42.91^{\circ}$ and $43.59^{\circ}$. Similarly, the $2 \theta$ values for the secondary phases $\mathrm{Al}_{6} \mathrm{Fe}_{2} \mathrm{Al}_{13} \mathrm{Fe}_{4}$ and $\mathrm{Al}_{13} \mathrm{Cr}_{2}$ shown in Figure $2 \mathrm{c}$ were found to be $36.53^{\circ}, 36.38^{\circ}$ and $41.53^{\circ}$, respectively. The $2 \theta$ values obtained in this investigation were found in good agreement with the values reported in the earlier investigations [30,31]. Based on the XRD profiles of the sintered samples, the average crystallite size was determined using the Scherrer equation [29]. The crystallite size of the samples was determined using the most intense peak of $\mathrm{Al}$ (111). The lowest crystallite size of the sintered samples was found to be $29 \pm 3 \mathrm{~nm}$ for $\mathrm{Al}-10 \mathrm{wt}$. \% $\mathrm{Fe}$, while the highest was $35 \pm 2 \mathrm{~nm}$ for pure $\mathrm{Al}$ sample. 
Figure 3 shows the SEM mapping of Al-10 wt. \% Fe sintered alloy obtained from the processed powder for $150 \mathrm{~h}$. From the figure, it is revealed that the Fe particles were homogeneously dispersed in the Al matrix. However, some bigger Fe rich particles were also observed. Similar observation could be made from the Figure 4, displaying the SEM mapping of Al-10 wt. \% Fe-5 wt. \% Cr sintered alloy. It is observed that the Fe and $\mathrm{Cr}$ particles were homogeneously dispersed in the $\mathrm{Al}$ matrix.

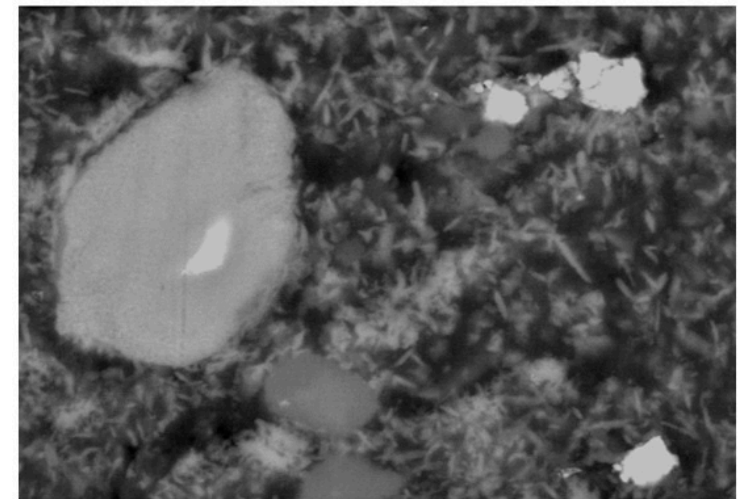

Electron Image 1

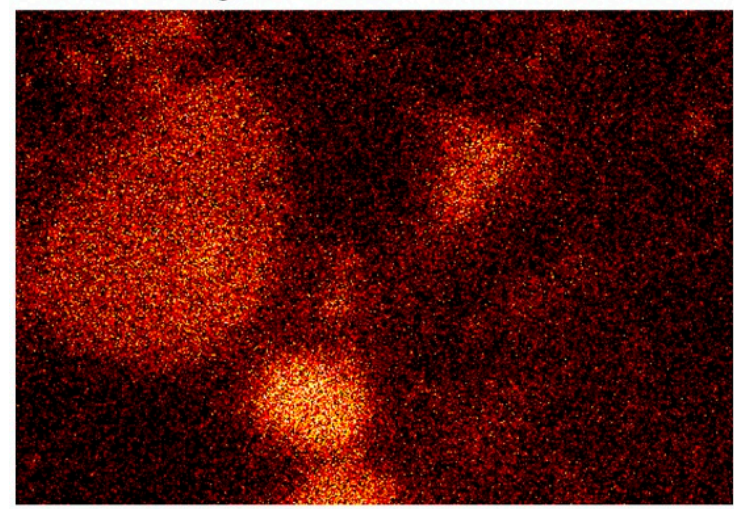

$\mathrm{Cr} \mathrm{Ka} 1$

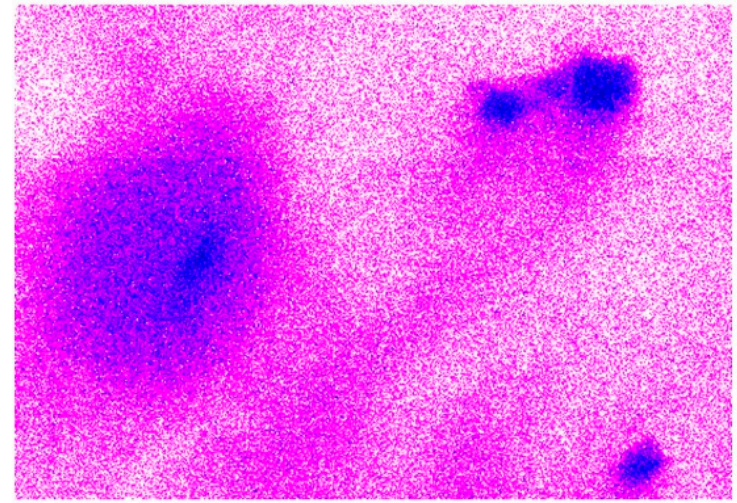

Al Ka1

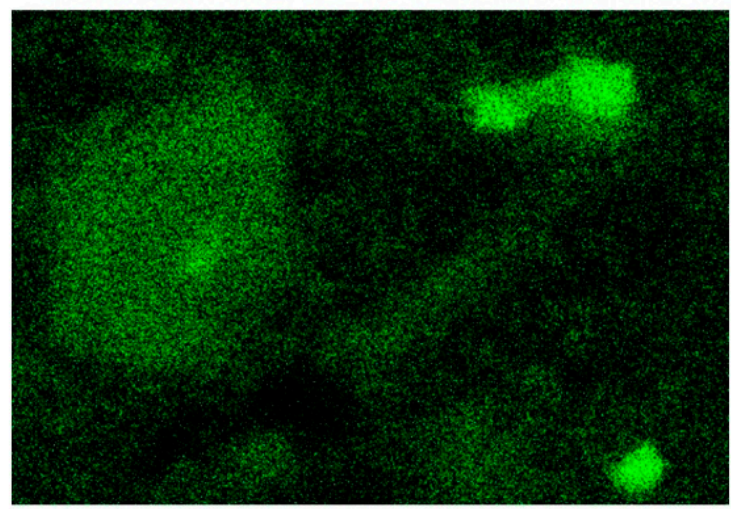

$\mathrm{Fe} \mathrm{Ka1}$

Figure 3. SEM mapping of the sintered bulk Al-10 wt. \% Fe-5 wt. \% Cr sample obtained from $150 \mathrm{~h}$ milled powder.

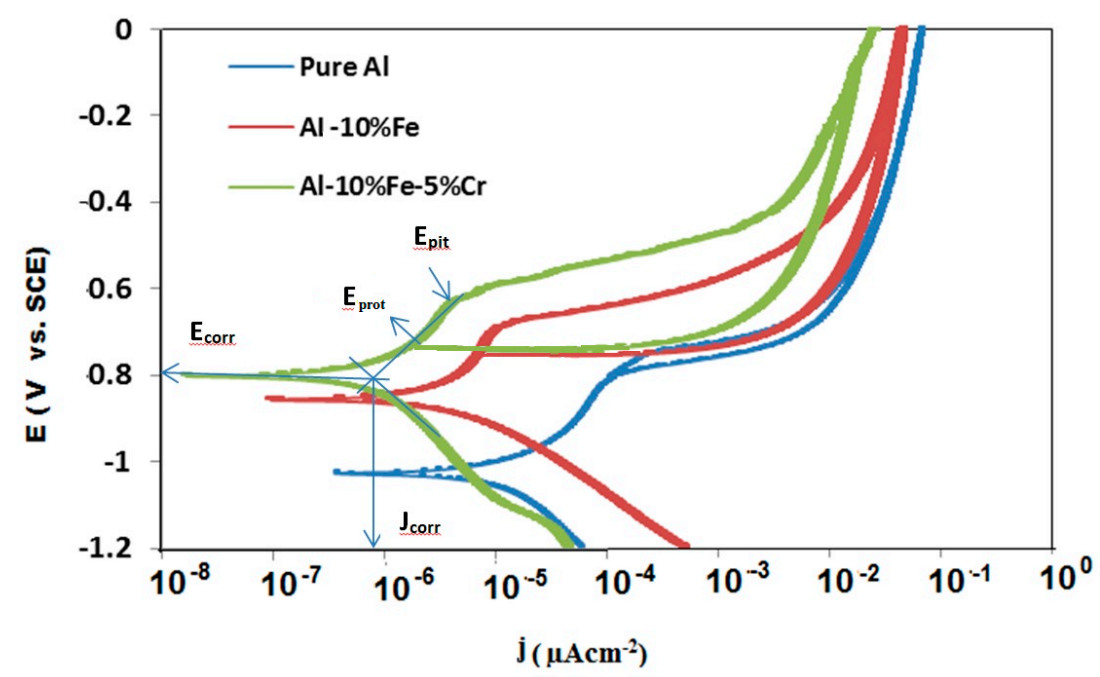

Figure 4. Potentiodynamic polarization curves for pure $\mathrm{Al}, \mathrm{Al}-10 \% \mathrm{Fe}$ and $\mathrm{Al}-10 \% \mathrm{Fe}-5 \% \mathrm{Cr}$ alloy immersed in $3.5 \% \mathrm{NaCl}$ after $1 \mathrm{~h}$ at room temperature. 


\subsection{Electrochemical Measurements}

The electrochemical responses of the nanocrystalline Al, Al-10 wt. \% Fe and Al-10 wt. \% Fe-5 wt. $\% \mathrm{Cr}$ sintered alloy, was investigated in an aerated $3.5 \% \mathrm{NaCl}$ solution for $1 \mathrm{~h}$ using the CPP method. Figure 4 shows the CPP curves that were used to determine the corrosion parameters. The values of the corrosion potential $\left(E_{\text {corr }}\right)$, corrosion current density $\left(j_{\text {corr }}\right)$ and polarization resistance $\left(R_{\mathrm{p}}\right)$ were calculated from the extrapolation of anodic and cathodic Tafel lines located next to the linearized current regions. The pitting potential (and the associated current density $j_{\text {pit }}$ ) was determined at the intersection of the extrapolated lines about the passivity breakdown. The protection (or repassivation) potential corresponds to the potential at which forward and reverse traces cross each other. All these corrosion parameters obtained from CPP curves are shown in Table 1.

Table 1. Potentiodynamic polarization parameters of pure $\mathrm{Al}, \mathrm{Al}-10 \% \mathrm{Fe}$ and $\mathrm{Al}-10 \% \mathrm{Fe}-5 \% \mathrm{Cr}$ alloy in $3.5 \% \mathrm{NaCl}$ at room temperature after $1 \mathrm{~h}$ immersion time.

\begin{tabular}{|c|c|c|c|c|c|c|}
\hline \multirow{2}{*}{ Materials } & \multicolumn{6}{|c|}{ Corrosion Parameters } \\
\hline & $E_{\text {corr }}, \mathrm{mV}$ & $j_{\text {corr }} \mu \mathrm{A} \cdot \mathrm{cm}^{-2}$ & $E_{\text {prot }}, \mathrm{mV}$ & $E_{\text {pit }}, \mathrm{mV}$ & $j_{\text {pit }}, \mu \mathrm{A} \cdot \mathrm{cm}^{-2}$ & $R_{\mathrm{p}}\left(\mathrm{k} \Omega \cdot \mathrm{cm}^{2}\right)$ \\
\hline $\mathrm{Al}$ & -1048 & 14.47 & -941 & -824 & 89.3 & 4.873 \\
\hline $\mathrm{Al}-10 \% \mathrm{Fe}$ & -842 & 3.06 & -754 & -694 & 10.33 & 9.356 \\
\hline $\mathrm{Al}-10 \% \mathrm{Fe}-5 \% \mathrm{Cr}$ & -802 & 0.796 & -706 & -633 & 4.84 & 19.005 \\
\hline
\end{tabular}

The effect of addition of the alloying elements Fe and $\mathrm{Cr}$ on $\mathrm{Al}$ is shown in Figure 5, where it can be seen from the polarization curves that both the binary and ternary alloy showed an active-passive behavior like pure Al. It is also observed that with addition of the alloying elements Fe and $\mathrm{Cr}$, the anodic current density decreases and cathodic current density increases significantly. This causes the corrosion potential to become nobler. Additionally, from the Table 1, it can be seen that the values of $E_{\text {corr }}$ and $E_{\text {pit }}$ shifted towards the positive direction, which decreases the values of anodic and cathodic currents, $j_{\text {corr }}$. From the polarization diagram the existence of pitting corrosion was also shown by the appearance of the hysteresis loop between the forward and reverse curves. The area between the loop is higher for the alloys than for Al that indicates more pitting or localized corrosion. It can also be seen from Table 1 that the polarization resistance $\left(R_{\mathrm{p}}\right)$ of $\mathrm{Al}$ alloy is increased due to the addition of Fe and $\mathrm{Cr}$. The increase in the polarization resistance of the alloy could be attributed to the presence of Fe and $\mathrm{Cr}$ in solid solution with $\mathrm{Al}$ after milling, which eventually led to the formation of intermetallics $\mathrm{Al}_{6} \mathrm{Fe}, \mathrm{Al}_{13} \mathrm{Fe}_{4}$ and $\mathrm{Al}_{13} \mathrm{Cr}_{2}$ during compaction and sintering process (shown in Figure 2). As mentioned earlier, the presence of intermetallics in the microstructure of the alloy are believed to increase the corrosion resistance of the alloy [16-18]. In addition, the presence of $\mathrm{Al}_{2} \mathrm{O}_{3}, \mathrm{Fe}_{2} \mathrm{O}_{3}$ and $\mathrm{Cr}_{2} \mathrm{O}_{3}$ was observed in XRD peak profiles of corroded sample. It is known that the existence of these oxides increases the corrosion resistance to the bulk alloy. The chloride ions do not enter into the oxide film but they are chemisorbed onto the oxide surface and act as a reaction partner, aiding the oxide to dissolve via the formation of oxy-chloride complexes. The microstructural stability decreases the dissolution of $\mathrm{Al}$ in the alloy and thereby inhibits the formation of $\mathrm{AlCl}_{4}$, an aluminum chloride complex which leads to pitting corrosion [32]. In another study, Frangini [33] reported that the alloying elements $\mathrm{Cr}$ or Ti enhance the $\mathrm{Al}_{2} \mathrm{O}_{3}$ protection of $\mathrm{NiAl}$ intermetallics by suppressing impassiveness of these scales. Additionally, the existence of passive layers of iron and aluminum oxides in the fabricated Al-Fe alloy also aids in corrosion protection. The increase in corrosion resistance $\left(R_{\mathrm{p}}\right)$ for Al-10 wt. $\%$ Fe and Al-10 wt. \% Fe-5 wt. \% Cr alloys is appreciably higher as compared with $R_{\mathrm{p}}$ of $\mathrm{Al}$, which indicates the addition of Fe and $\mathrm{Cr}$ to $\mathrm{Al}$ favored the increment of $R_{\mathrm{p}}$.

EIS experiments are usually performed to characterize the corrosion behavior of metals and alloys. In this investigation, EIS experiments were performed on the nanocrystalline alloys to determine the corrosion parameters. Nyquist plots obtained at the open-circuit potential for the pure $\mathrm{Al}, \mathrm{Al}-10 \% \mathrm{Fe}$ and $\mathrm{Al}-10 \% \mathrm{Fe}-5 \% \mathrm{Cr}$ alloy after one hour of exposure time are shown on Figure 5 . The impedance parameters from the Nyquist plots were evaluated by comparing the experimental results with 
an equivalent circuit model (ECM) as shown in Figure 6. From this ECM the solution resistance $\left(R_{\mathrm{S}}\right)$, the polarization resistance or charge transfer resistance at the electrode/solution interface $\left(R_{\mathrm{p}}\right.$ or $\left.R_{\mathrm{ct}}\right)$, and the $R_{\mathrm{f}}$, resistance of the film that is related to the contribution of the corrosion products and $C_{\mathrm{f}}$ its capacitance, were determined [34]. The value of these parameters obtained is shown in Table 2. Constant phase elements (CPEs) are substituted for the capacitive elements: $\mathrm{CPE}_{\mathrm{dl}}$ or $C_{\mathrm{dl}}$ represents the double-layer capacitance and $C P E_{\mathrm{f}}$ or $C_{\mathrm{f}}$ the pseudo-capacitance, to give a more accurate fit. Of the various corrosion parameters, $R_{\mathrm{ct}}$ is the parameter that defines the corrosion resistance of the alloys. It is well known that the $R_{\mathrm{ct}}$ value is inversely proportional to $j_{\text {corr }}$. This implies that a higher value of $R_{\text {ct }}$ corresponds to a lower $j_{\text {corr }}$.

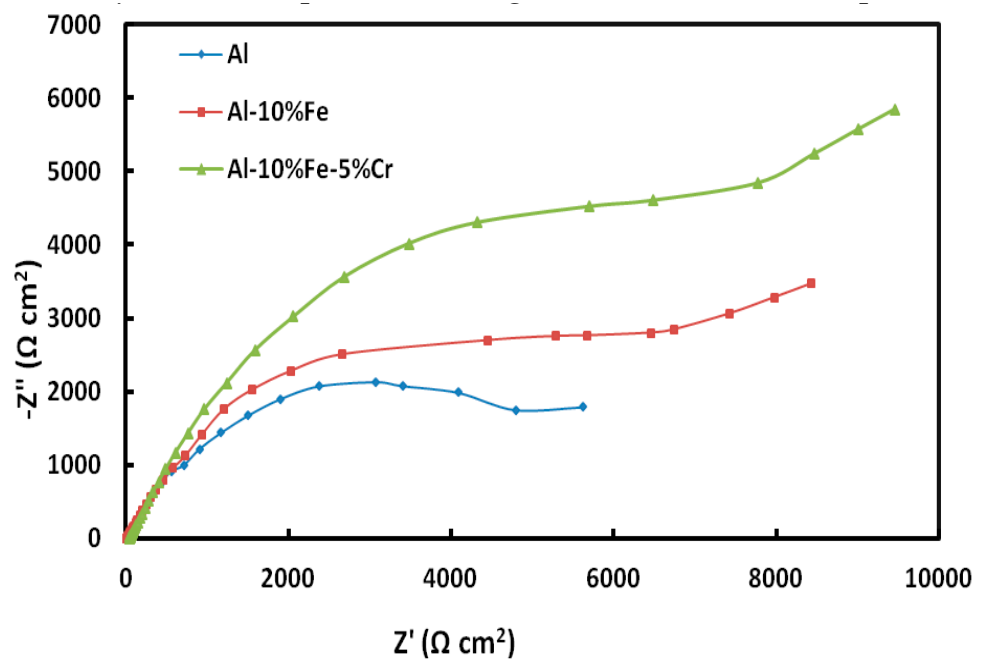

Figure 5. Nyquist plot of pure $\mathrm{Al}, \mathrm{Al}-10 \% \mathrm{Fe}$ and $\mathrm{Al}-10 \% \mathrm{Fe}-5 \% \mathrm{Cr}$ alloy immersed in $3.5 \% \mathrm{NaCl}$ after $1 \mathrm{~h}$ at room temperature.

Table 2. Electrochemical Impedance parameters for pure $\mathrm{Al}, \mathrm{Al}-10 \% \mathrm{Fe}$ and $\mathrm{Al}-10 \% \mathrm{Fe}-5 \% \mathrm{Cr}$ alloy immersed in $3.5 \% \mathrm{NaCl}$ after $1 \mathrm{~h}$ at room temperature.

\begin{tabular}{|c|c|c|c|c|c|c|c|}
\hline \multirow{3}{*}{ Materials } & \multicolumn{7}{|c|}{ EIS Parameters } \\
\hline & \multirow{2}{*}{$R_{\mathrm{S}}, \Omega \mathrm{cm}^{2}$} & \multicolumn{2}{|l|}{$Q 1$} & \multirow{2}{*}{$R_{\mathrm{ct}}\left(\mathrm{k} \Omega \mathrm{cm}^{2}\right)$} & \multicolumn{2}{|l|}{$Q 2$} & \multirow{2}{*}{$R_{\mathrm{f}}\left(\mathrm{k} \Omega \mathrm{cm}^{2}\right)$} \\
\hline & & $C_{\mathrm{dl}}\left(\mu \mathrm{Mho} \mathrm{cm}^{-2}\right)$ & $n$ & & $C_{\mathrm{f}}\left(\mu \mathrm{Mho} \mathrm{\textrm {cm } ^ { - 2 } )}\right.$ & $n$ & \\
\hline $\mathrm{Al}$ & 3.85 & 248.4 & 0.978 & 1.1 & 616 & 0.57 & 2.8 \\
\hline $\mathrm{Al}-10 \% \mathrm{Fe}$ & 5.38 & 180.1 & 1.00 & 1.8 & 523 & 0.62 & 6.2 \\
\hline $\mathrm{Al}-10 \% \mathrm{Fe}-5 \% \mathrm{Cr}$ & 5.36 & 48.1 & 0.999 & 7.05 & 363 & 0.54 & 17.1 \\
\hline
\end{tabular}

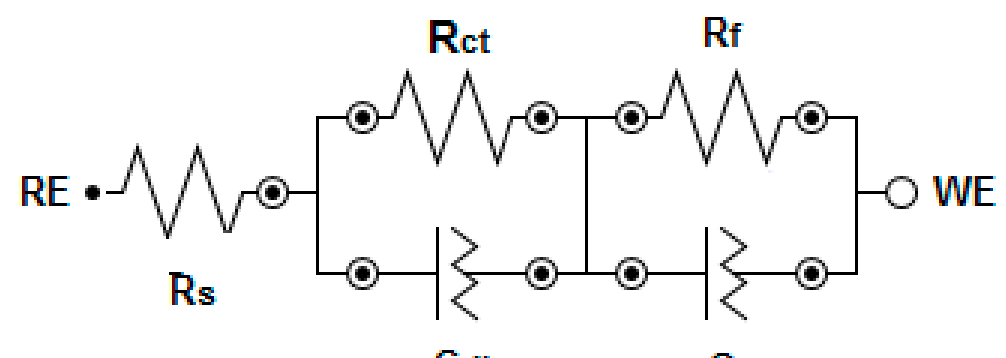

CdI

Figure 6. Equivalent circuit fitting for EIS.

The Nyquist plot shows in Figure 5 consist of one capacitive semicircle followed by a tail. The high frequency tail could be related with the mass transfer reaction from the alloy into the electrolyte through the electrochemical double layer, while the low frequency loop could be linked to the formation of a passive layer, possibly $\mathrm{Al}_{2} \mathrm{O}_{3}, \mathrm{Fe}_{2} \mathrm{O}_{3}, \mathrm{Cr}_{2} \mathrm{O}_{3}$, or other corrosion products. 
From the Nyquist plot, it is noted that the diameter of the loop/arc that gives the charge-transfer resistance $\left(R_{\mathrm{ct}}\right)$ of corrosion reaction increased substantially with the addition of alloying elements. The results from Table 2 also indicate that the values of both $R_{\mathrm{ct}}$ and $R_{\mathrm{f}}$ increase with the addition of alloying elements $\mathrm{Fe}$ and $\mathrm{Cr}$. The higher values of $R_{\mathrm{ct}}$ indicate the formation of a stable oxide layer on the surface of Al-10 wt. \% Fe-5 wt. \% Cr alloy, that offer a significant increase in the corrosion resistance of the alloy.

The impedance of constant phase elements $(\mathrm{CPE})$ is defined by the expression: $Z_{\mathrm{CPE}}=1 / Y(j \omega)$, where, $Y$ is the CPE constant, $\omega$ is the angular frequency (in $\operatorname{rad~s}^{-1}$ ), $j^{2}=-1$ is the imaginary number and $n$ is the CPE exponent varies from $-1<n<1$. It has been reported [35] earlier that depending on the value of $n$, the value of CPEs may be resistance or capacitance or inductance. In the current study, $n$ values vary from 0.96 to 0.99 , so the constant phase elements $\left(\mathrm{CPE}_{\mathrm{d} 1}\right)$ indicates double layer capacitors with some pores, i.e., the passive film formed on $\mathrm{Al}$ alloy surface is non homogenous with little porosities [36]. Alternatively, $\mathrm{CPE}_{\mathrm{f}}$ represents Warburg impedance $(\mathrm{W})$ due to its $n$ value between 0.51 to 0.61 , which agrees the passivity of the surface of $\mathrm{Al}$ alloys in $3.5 \% \mathrm{NaCl}$ and the mass transport is restricted by the development of surface corrosion products and/or oxide film [37]. It is seen that in most cases, the value of $R_{\mathrm{f}}$ is higher than the resistance of double layer $R_{\mathrm{ct}}$. This implies that the corrosion protection is caused mainly by the inner barrier layer [38].The EIS measurements obtained in this investigation are in good agreement with the CPP data indicating that the ternary Al-10 wt. \% Fe-5 wt. \% Cr alloy has highest resistance against the corrosion due to formation of passive layer in the aerated $3.5 \% \mathrm{NaCl}$ solution.

The Bode plot obtained from the EIS data was examined to observe the changes on the surface of the sample during EIS experiment. Figure 7 shows the Bode plot of pure $\mathrm{Al}, \mathrm{Al}-10 \% \mathrm{Fe}$ and $\mathrm{Al}-10 \%$ $\mathrm{Fe}-5 \% \mathrm{Cr}$ alloy. From the Figure 7 the total impedance values of pure Al, Al-10\% Fe and Al-10\% $\mathrm{Fe}-5 \% \mathrm{Cr}$ alloy obtained after $1 \mathrm{~h}$ immersion in $\mathrm{NaCl}$ was found to be $5.02 \mathrm{k} \Omega \mathrm{cm}^{2}, 9.4 \mathrm{k} \Omega \mathrm{cm}^{2}$ and $20.5 \mathrm{k} \Omega \mathrm{cm}^{2}$. It is seen from the figure that impedance value of Al-10 wt. \% Fe-5 wt. \% Cr alloy is the highest. The high impedance value implies that this alloy has good resistance against $\mathrm{NaCl}$ solution. The increase in impedance values implies that the corrosion resistance of the Al alloy increase with the addition of Fe and $\mathrm{Cr}$.

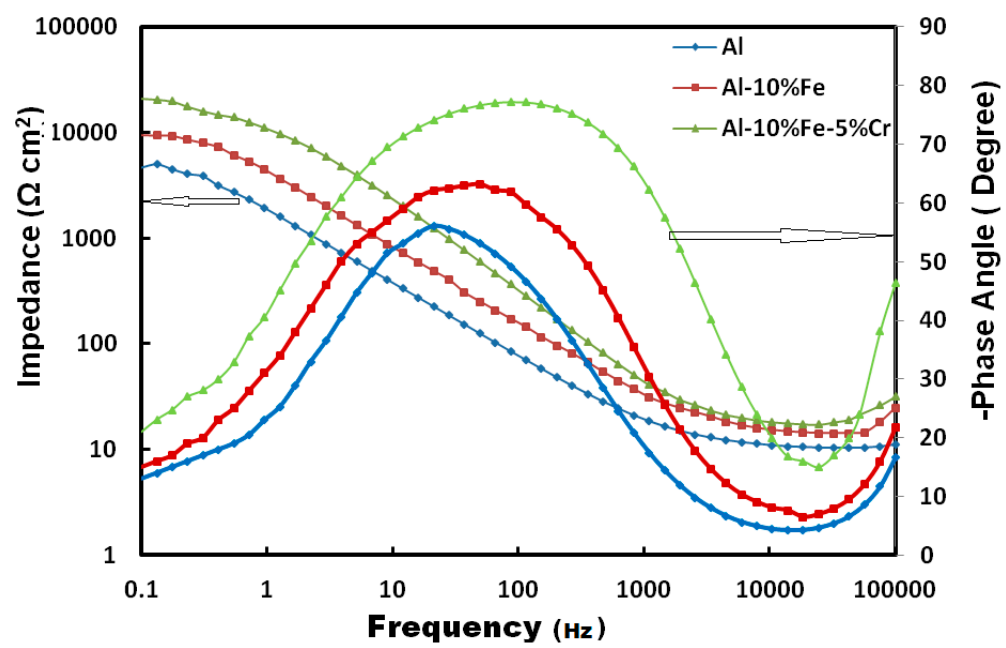

Figure 7. Bode plot of pure $\mathrm{Al}, \mathrm{Al}-10 \% \mathrm{Fe}$ and $\mathrm{Al}-10 \% \mathrm{Fe}-5 \% \mathrm{Cr}$ alloy immersed in $3.5 \% \mathrm{NaCl}$ after $1 \mathrm{~h}$ at room temperature.

The Bode-phase diagram shown in Figure 7 indicates the presence of two time constants which represent a highly capacitive behavior, typical to passive materials.

The capacitive behavior is indicated from medium to low frequencies by phase angles approaching $75^{\circ}$, suggesting that a very stable film is formed on surface of Al-10 wt. \% Fe-5 wt. \% Cr alloy. 


\subsection{Microstructural Characterization}

The SEM image of the corroded surface of pure Al shows in Figure 8a described that the surface of $\mathrm{Al}$ is completely corroded, which confirms the aggressive action of the $\mathrm{NaCl}$ on $\mathrm{Al}$. From the EDX analysis the atomic percentage of the identified elements on the corroded surface recorded $76.22 \% \mathrm{Al}$, and $23.78 \% \mathrm{O}$. This shows that corrosion products on $\mathrm{Al}$ surface were most possibly aluminum oxide, $\mathrm{Al}_{2} \mathrm{O}_{3}$, which protects the surface and hides the pits that caused the increase of current.

The SEM image of Al-10\% Fe alloy in Figure $8 \mathrm{~b}$ shows that the surface developed very thick oxide film and/or corrosion products layer. The atomic percentages for the elements found by the EDX profile analysis were Al-70.33\%, Fe-5.49\%, O-21.61\%, Cl-2.57\%. The EDX analysis before corrosion gives A1-90.67\% and Fe-9.33\%. This confirms that the layer formed on the surface of the alloy was mainly $\mathrm{Al}_{2} \mathrm{O}_{3}$. The presence of very low concentration of Fe proves that the surface of the alloy is completely covered with the oxide film.

The SEM image in Figure 8c of the corroded surface of Al-10\% Fe $-5 \% \mathrm{Cr}$ alloy shows that a large numbers of shallow pits were visible with homogeneous passive layer formed on the surface of the alloy and its EDX analysis recorded weight percentages of $29.32 \% \mathrm{O}, 60.95 \% \mathrm{Al}, 1.38 \% \mathrm{Cl}, 6.28 \% \mathrm{Fe}$ and $2.07 \% \mathrm{Cr}$. However, the EDX investigation of $\mathrm{Al}-10 \% \mathrm{Fe}-5 \% \mathrm{Cr}$ alloy before corrosion indicated the presence of $84.59 \mathrm{wt}$. \% Al, $10.31 \mathrm{wt}$. \% Fe and $5.1 \mathrm{wt}$. \% $\mathrm{Cr}$ in the alloy. A comparison between the two cases (before and after corrosion) clearly shows a decrease in Al content in the alloy after immersion. This decrease could be attributed to the dissolution of Al due to the chloride ions attack.

Additionally, the presence of high percentage of oxygen and low concentration of Fe and $\mathrm{Cr}$ in the alloy after immersion clearly indicate the formation of an oxide layer/or film on its outer surface.

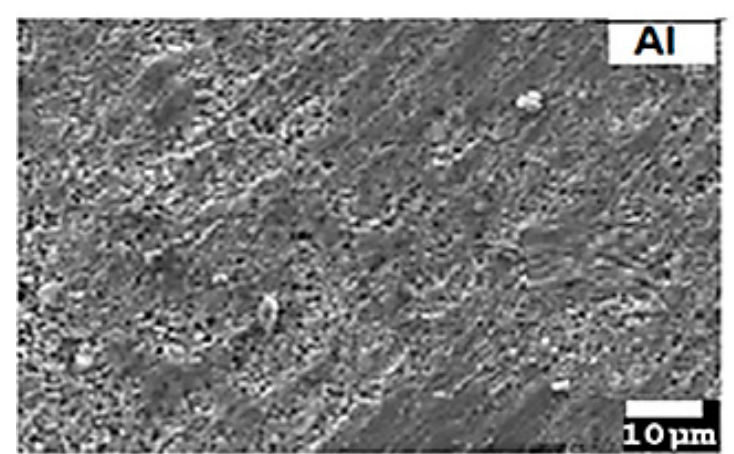

(a)

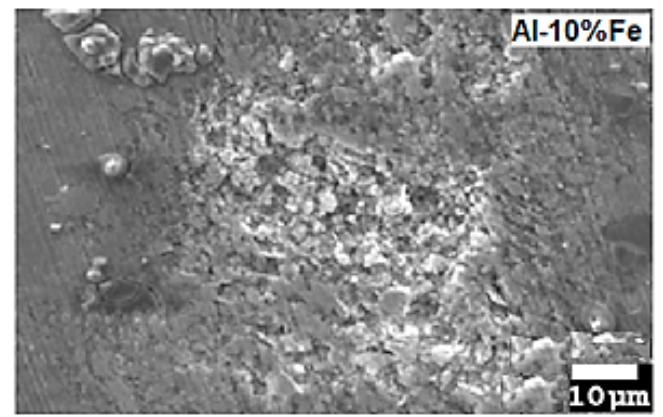

(b)

\begin{tabular}{|c|c|}
\hline Elements & Weight $\%$ \\
\hline O & 23.78 \\
Al & 76.22 \\
\hline
\end{tabular}

\begin{tabular}{|c|c|}
\hline Elements & Weight $\%$ \\
\hline $\mathrm{O}$ & 21.61 \\
$\mathrm{Al}$ & 70.33 \\
$\mathrm{Fe}$ & 5.49 \\
$\mathrm{Cl}$ & 2.57 \\
\hline
\end{tabular}

Figure 8. Cont. 


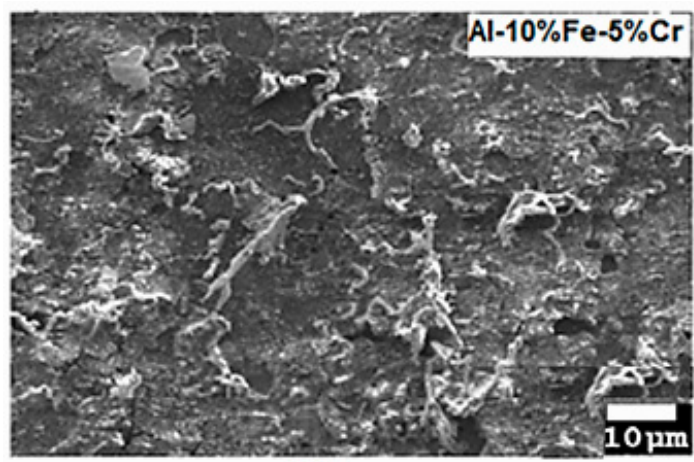

\begin{tabular}{|cc|}
\hline Elements & Weight $\%$ \\
\hline $\mathrm{O}$ & 29.32 \\
$\mathrm{Al}$ & 60.95 \\
$\mathrm{Fe}$ & 6.28 \\
$\mathrm{Cr}$ & 2.07 \\
$\mathrm{Cl}$ & 1.38 \\
\hline
\end{tabular}

(c)

Figure 8. SEM micrograph and EDX profile analysis obtained on the (a) nanocrystalline Al, (b) Al-10\% Fe and (c) $\mathrm{Al}-10 \% \mathrm{Fe}-5 \% \mathrm{Cr}$ alloy after its immersion in $3.5 \% \mathrm{NaCl}$ for $1 \mathrm{~h}$.

In this investigation, the corrosion resistance of the nanocrystalline pure $\mathrm{Al}$ was observed to be lower than the other two alloys experimented. This could be due to the large surface area and the presence of many active centers in nanocrystalline pure Al. The improved corrosion resistance of $\mathrm{Al}-10 \% \mathrm{Fe}$ and $\mathrm{Al}-10 \% \mathrm{Fe}-5 \% \mathrm{Cr}$ alloys can be attributed to the combined influence of high energy ball milling (HEBM) and alloying addition such as Fe and Cr. HEBM produced extended solid solubility (of Fe and $\mathrm{Cr}$ in $\mathrm{Al}$ ), and a nanocrystalline structure, which is known to influence passivation abilities and pitting resistance in other metal alloy systems [39]. The incorporation of $\mathrm{Cr}$ in solid solution improves the corrosion resistance by stabilizing the passive film, increasing repassivation kinetics, and decreasing the difference between the electrochemical characteristics of matrix and intermetallics [40].

Thus, the SEM/EDX study established that the presence of $10 \% \mathrm{Fe}$, passivates $\mathrm{Al}$ to a great extent by reducing both uniform and pitting corrosion and that effect was enhanced by adding $5 \% \mathrm{Cr}$ as an alloying element to the $\mathrm{Al}-10 \% \mathrm{Fe}$ alloy.

Figure 9a-c shows the XRD peak profiles for the sintered pure $\mathrm{Al}, \mathrm{Al}-10 \mathrm{wt}$. \% Fe and $\mathrm{Al}-10 \mathrm{wt}$. \% Fe- 5 wt. \% Cr sintered alloy after immersion in 3.5\% NaCl solution. The XRD profiles clearly indicate the presence of oxide layer/films on the surface of all the alloys investigated in this study. The results from the XRD are in accordance with the SEM/EDX analysis which also showed the presence of oxygen (oxide) in all the alloys after immersion. This oxide film passivates the surface, which increases the corrosion resistance of $\mathrm{Al}$ alloy.

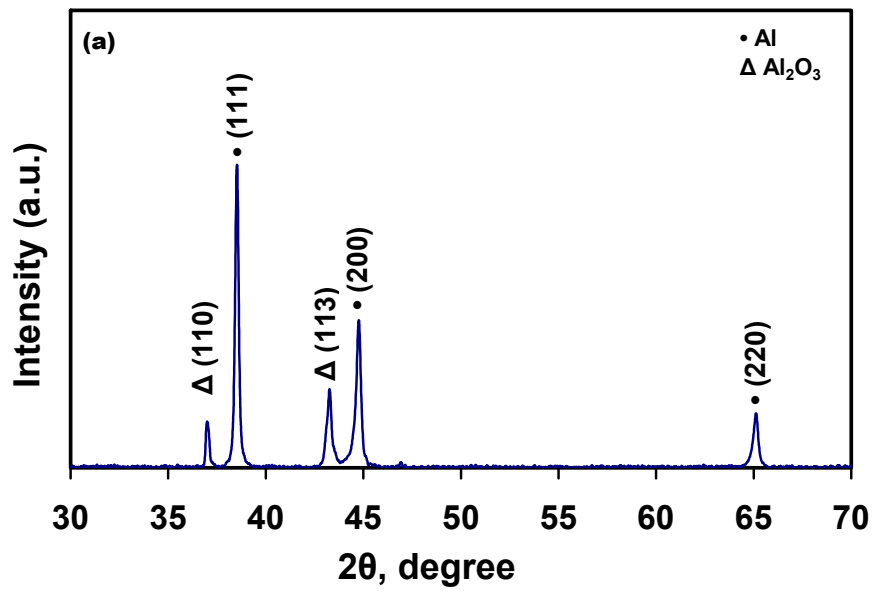

Figure 9. Cont. 

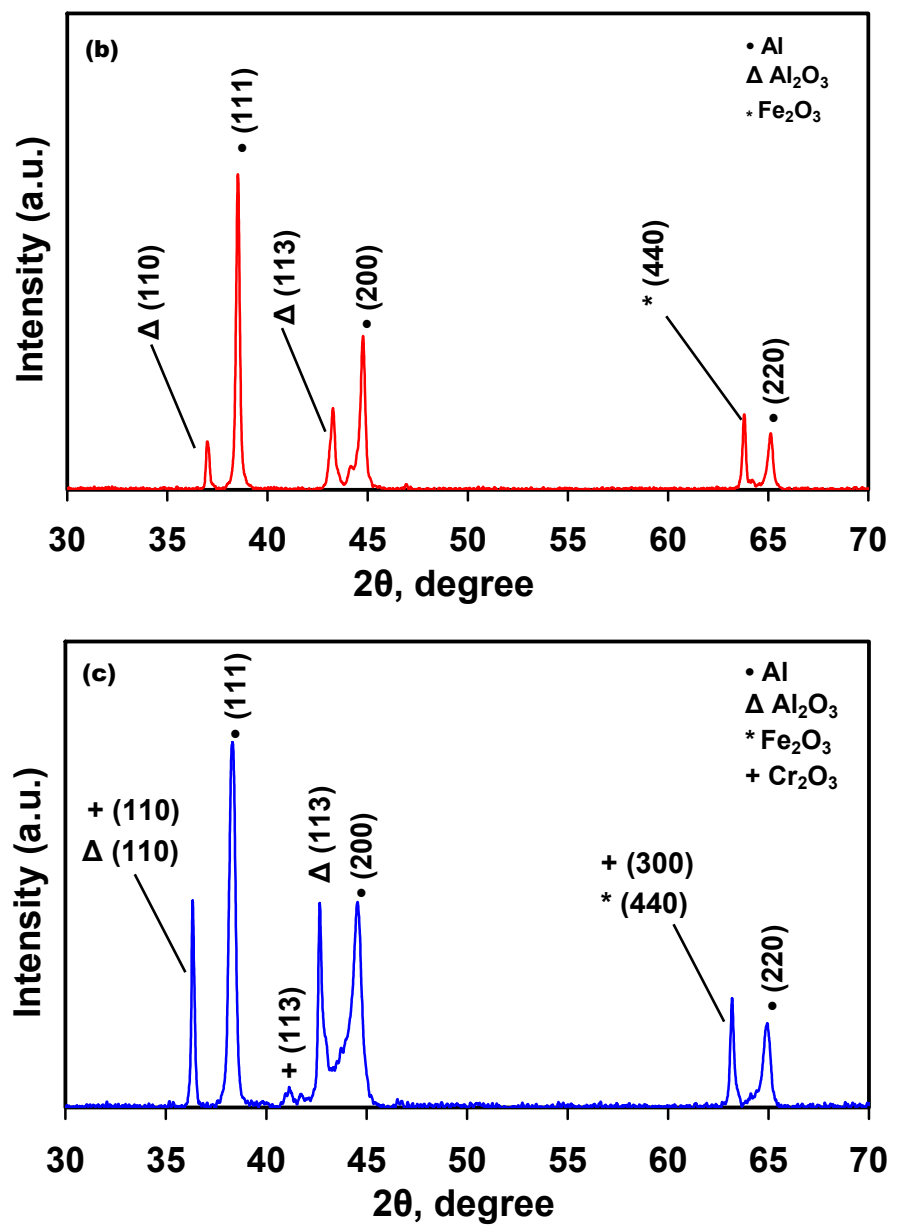

Figure 9. XRD analysis obtained on the nanocrystalline $\mathrm{Al}(\mathbf{a}), \mathrm{Al}-10 \% \mathrm{Fe}(\mathbf{b})$ and $\mathrm{Al}-10 \% \mathrm{Fe}-5 \% \mathrm{Cr}$ (c) alloy after corrosion.

\section{Conclusions}

Nanocrystalline pure $\mathrm{Al}, \mathrm{Al}-10 \% \mathrm{Fe}$ and $\mathrm{Al}-10 \% \mathrm{Fe}-5 \%$ Cr bulk alloy was fabricated by mechanical alloying (MA) technique and high frequency induction heat sintering (HFIHS). Corrosion resistance was evaluated in 3.5\% NaCl solution using CPP and EIS techniques. Microstructure of sintered and corroded alloys was performed using SEM equipped with EDX. The XRD results showed that the crystallite size (of the order of $\mathrm{nm}$ ) is nearly same for all The experimental results indicated that the fabricated alloys showed excellent resistance to corrosion due to enhanced microstructural stability along with the formation of stable oxide layer. The CPP results showed that the addition of $10 \mathrm{wt} . \%$ Fe to nanocrystalline pure $\mathrm{Al}$ had resulted in an increase in the corrosion resistance. Further, addition of $5 \mathrm{wt}$ \% Cr to the Al-10 wt. \% Fe alloy has also resulted in an increase in corrosion resistance, when compared to the corrosion resistance of nanocrystalline pure Al.

Acknowledgments: This project was funded by the National Plan for Science, Technology and Innovation (MAARIFAH), King Abdulaziz City for Science and Technology, Kingdom of Saudi Arabia, Award Number (12-NAN2635-02).

Author Contributions: Asiful Hossain Seikh designed the work and conducted the corrosion experiments. Muneer Baig fabricated the alloys and helped in writing the draft of manuscript. Mohammed Asif Alam participated in performing the corrosion tests and wrote the draft manuscript. Hany Rizk Ammar helped in manufacturing the alloy and edited the final manuscript.

Conflicts of Interest: The authors declare no conflict of interest. 


\section{References}

1. Handbook of Aluminum: Vol. 1-Physical Metallurgy and Processes; Totten, G.E., MacKenzie, D.S., Eds.; Marcel Dekker Inc.: New York, NY, USA, 2003.

2. Gonzalez-Rodriguez, J.G.; Salazar, M.; Luna-Ramirez; Porcayo-Calderon, J.; Rosas, G.; Villfane, A.M. Effect of $\mathrm{Li}, \mathrm{Ce}$ and $\mathrm{Ni}$ on the corrosion resistance of $\mathrm{FeAl}$ in molten $\mathrm{Na}_{2} \mathrm{SO}_{4}$ and $\mathrm{NaVO}_{3}$. High Temp. Mater. Proc. 2004, 23, 177-183. [CrossRef]

3. Sasaki, T.; Mukai, T.; Hono, K. A high-strength bulk nanocrystalline Al-Fe alloy processed by mechanical alloying and spark plasma sintering. Scr. Mater. 2007, 57, 189-192. [CrossRef]

4. Lu, L.; Zhang, Y. Influence of process control agent on interdiffusion between $\mathrm{Al}$ and $\mathrm{Mg}$ during mechanical alloying. J. Alloys Compd. 1999, 290, 279-283. [CrossRef]

5. Mishra, R.; Balasubramaniam, R. Effect of nanocrystalline grain size on the electrochemical and corrosion behavior of nickel. Corros. Sci. 2004, 46, 3019-3029. [CrossRef]

6. Luo, W.; Xu, Y.; Wang, Q.; Shi, P.; Yan, M. Effect of grain size on corrosion of nanocrystalline copper in $\mathrm{NaOH}$ solution. Corros. Sci. 2010, 52, 3509-3513. [CrossRef]

7. Kim, S.; Aust, K.; Erb, U.; Gonzalez, F.; Palumbo, G. A comparison of the corrosion behaviour of polycrystalline and nanocrystalline cobalt. Scr. Mater. 2003, 48, 1379-1384. [CrossRef]

8. Srinivasan, P.B.; Heitmann, V.; Dietzel, W. Stress corrosion cracking behaviourof chromated AA2024 T351 alloy in chloride solution. Corros. Sci. Eng. Technol. 2004, 39, 174-177. [CrossRef]

9. Gudi'c, S.; Smoljko, I.; Kli`ski'c, M. The effect of small addition of tin and indium onthe corrosion behavior of aluminium in chloride solution. J. Alloys Compd. 2010, 505, 54-63. [CrossRef]

10. Li, S.; Zhang, H.; Liu, J. Corrosion behavior of aluminumalloy 2024-T3 by 8-hydroxy-quinoline and its derivative in 3.5\% chloride solu-tion. Trans. Nonferr. Met. Soc. China 2007, 17, 318-325. [CrossRef]

11. Shen, D.; Li, G.; Guo, C.; Zou, J.; Cai, J.; He, D.; Ma, H.; Liu, F. Microstructure and corrosion behavior of micro-arc oxidationcoating on 6061 aluminum alloy pre-treated by high temperature oxidation. Appl. Surf. Sci. 2013, 287, 451-456. [CrossRef]

12. Cai, C.; Zhang, Z.; Cao, F.; Gao, Z.; Zhang, J.; Cao, C. Analysis of pitting corrosion behavior of pure $\mathrm{Al}$ in sodium chloride solutionwith the wavelet technique. J. Electroanal. Chem. 2005, 578, 143-150. [CrossRef]

13. Ensinger, W.; Lensch, O.; Matsutani, T.; Kiuchi, M. Corrosion performance of thinamorphous carbon films on aluminum formed by ion beam-based coating tech-niques. Surf. Coat. Technol. 2005, 196, 231-135. [CrossRef]

14. Jafarzadeh, K.; Shahrabi, T.; Hosseini, M.G. Effect of cathodic polarisation on pit-ting corrosion of AA5083-H321 aluminium-magnesium alloy in stagnant 3.5\% NaCl solution. Corros. Sci. Eng. Technol. 2009, 44, 144-148. [CrossRef]

15. Ralston, K.D.; Birbilis, N. Effect of grain size on corrosion: A review. Corrosion 2010, 66, 075005/1-075005/13. [CrossRef]

16. Gupta, R.K.; Fabijanic, D.; Dorin, T.; Qiu, Y.; Wang, J.T.; Birbilis, N. Simultaneous improvement in the strength and corrosion resistance of $\mathrm{Al}$ via high-energy ball milling and $\mathrm{Cr}$ alloying. Mater. Des. 2015, 84, 270-276. [CrossRef]

17. Gupta, R.K.; Fabijanic, D.; Zhang, R.; Birbilis, N. Corrosion behaviour and hardness of in situ consolidate nanostructured $\mathrm{Al}$ and $\mathrm{Al}-\mathrm{Cr}$ alloys produced via high-energy ball milling. Corros. Sci. 2015, 98, 643-650. [CrossRef]

18. Dorin, T.; Stanford, N.; Birbilis, N.; Gupta, R.K. Infuence of cooling rate on the microstructure and corrosion behaviour of Al-Fe Alloys. Corros. Sci. 2015, 100, 396-403. [CrossRef]

19. Sherif, E.M.; Ammar, H.R.; Khalil, K.A. Effects of copper and titanium on the corrosion behavior of newly fabricated nanocrystalline aluminum in natural seawater. Appl. Surf. Sci. 2014, 301, 142-148. [CrossRef]

20. Ghosh, S.; Dey, G.; Dusane, R.; Grover, A. Improved pitting corrosion behaviour of electrodeposited nanocrystalline $\mathrm{Ni}-\mathrm{Cu}$ alloys in $3.0 \mathrm{wt}$ \% NaCl solution. J. Alloys Compd. 2006, 426, 235-243. [CrossRef]

21. Liu, L.; Li, Y.; Wang, F. Electrochemical corrosion behavior of nanocrystalline materials-A review. J. Mater. Sci. Technol. 2010, 26, 1-14. [CrossRef]

22. Miyamoto, H.; Harada, K.; Mimaki, T.; Vinogradov, A.; Hashimoto, S. Corrosion of ultra-fine grained copper fabricated by equal-channel angular pressing. Corros. Sci. 2008, 50, 1215-1220. [CrossRef]

23. Birbilis, N.; Estrin, Y. Corrosion of pure $\mathrm{Mg}$ as a function of grain size and processing route. Adv. Eng. Mater. 2008, 10, 579-582. 
24. Osório, W.R.; Freire, C.M.; Garcia, A. The role of macrostructural morphology and grain size on the corrosion resistance of $\mathrm{Zn}$ and Al castings. Mater. Sci. Eng. 2005, 402, 22-32. [CrossRef]

25. Ralston, K.; Fabijanic, D.; Birbilis, N. Effect of grain size on corrosion of high purity aluminium. Electrochim. Acta 2011, 56, 1729-1736. [CrossRef]

26. Barbucci, A.; Farne, G.; Matteazzi, P.; Riccieri, R.; Cerisola, G. Corrosion behaviour of nanocrystalline Cu90Ni10 alloy in neutral solution containing chlorides. Corros. Sci. 1998, 41, 463-475. [CrossRef]

27. Chianpairot, A.; Lothongkum, G.; Schuh, C.A.; Boonyongmaneerat, Y. Corrosion of nanocrystalline Ni-W alloys in alkaline and acidic $3.5 \mathrm{wt}$. \% NaCl solutions. Corros. Sci. 2011, 53, 1066-1071. [CrossRef]

28. Seikh, A.H.; Baig, M.; Ammar, H.R. Corrosion Behavior of Nanostructure Al-Fe Alloy Processed by Mechanical Alloying and High Frequency Induction Heat Sintering. Int. J. Electrochem. Sci. 2015, 10, 3054-3064.

29. Patterson, A. The Scherrer formula for X-ray particle size determination. Phys. Rev. 1939, 56, $978-982$. [CrossRef]

30. Zawrah, M.; Shaw, L. Microstructure and hardness of nanostructured Al-Fe-Cr-Ti alloys through mechanical milling. Mater. Sci. Eng. A 2003, 355, 37-49. [CrossRef]

31. Shaw, L.; Luo, H.; Villegas, J.; Miracle, D. Thermal stability of nanostructured $\mathrm{Al}_{93} \mathrm{Fe}_{3} \mathrm{Cr}_{2} \mathrm{Ti}_{2}$ alloys prepared via mechanical alloying. Acta. Mater. 2003, 51, 2647-2663. [CrossRef]

32. Sherif, E.M.; Park, S.-M. Effects of 1,4-naphthoquinone on aluminum corrosion in $0.50 \mathrm{M}$ sodium chloride solutions. Electrochim. Acta 2006, 51, 1313-1321. [CrossRef]

33. Frangini, S.; Masci, A. Intermetallic FeAl based coatings deposited by the electrospark technique: Corrosion behavior in molten $(\mathrm{Li}+\mathrm{K})$ carbonate. Surf. Coat. Technol. 2004, 184, 31-39. [CrossRef]

34. Ma, H.; Chen, S.; Niu, L.; Zhao, S.; Li, S.; Li, D. Inhibition of copper corrosion by several Schiff bases in aerated halide solutions. J. Appl. Electrochem. 2002, 32, 65-72. [CrossRef]

35. Singh, A.K.; Shukla, S.K.; Singh, M.; Quraishi, M.A. Inhibitive effect of ceftadizime on corrosion of mild steel in hydrochloric acid solution. Mater. Chem. Phys. 2011, 129, 68-76. [CrossRef]

36. Sherif, E.M.; Park, S.-M. Effects of 2-amino-5-ethylthio-1,3,4-thiadiazole on copper corrosion as a corrosion inhibitor in aerated acidic pickling solutions. Electrochim. Acta 2006, 51, 6556-6562. [CrossRef]

37. Rehim, S.S.A.; Hassan, H.H.; Amin, M.A. Corrosion and corrosion inhibition of Aland some alloys in sulphate solutions containing halide ions investigated by an impedance technique. Appl. Surf. Sci. 2002, 187, 279-290. [CrossRef]

38. Zhou, Y.L.; Ninomi, M.; Akahori, T.; Fukui, H.; Toda, H. Corrosion resistance and biocompatibility of Ti-Ta alloys for biomedical applications. Mater. Sci. Eng. 2005, 398, 28-36. [CrossRef]

39. Gupta, R.K.; Birbilis, N. The influence of nanocrystalline structure and processing route on corrosion of stainless steel: A review. Corros. Sci. 2015, 92,1-15. [CrossRef]

40. Frankel, G.S.; Newman, R.C.; Jahnes, C.V.; Russak, M.A. On the pitting resistance of sputter-deposited aluminum alloys. J. Electrochem. Soc. 1993, 140, 2192-2197. [CrossRef]

(C) 2016 by the authors; licensee MDPI, Basel, Switzerland. This article is an open access article distributed under the terms and conditions of the Creative Commons Attribution (CC-BY) license (http://creativecommons.org/licenses/by/4.0/). 